\title{
PARTIAL REPLACEMENT OF CEMENT IN CONCRETE USING WASTE GLASS POWDER AND M-SAND AS FINE AGGREGATE
}

\author{
Shruthi.S $\mathbf{1}$, Chandrakala $\mathbf{S}^{\mathbf{2}}$, G Narayana $^{\mathbf{3}}$ \\ ${ }^{I}$ Post graduate student, Department of civil engineering, SJCIT Chickaballapur, Karnataka, India \\ ${ }^{2}$ Assistant professor, Department of civil engineering, SJCIT College Chickaballapur, Karnataka, India \\ ${ }^{3}$ Head of the Department, Department of Civil Engineering, SJCIT, Karnataka, India
}

\begin{abstract}
A huge amount of concrete is consumed by the construction industry. About 35\% volume of concrete is comprised of sand. A good quality concrete is produced by careful mixing of cement, fine and coarse aggregates, water and admixtures as needed to obtain an optimum quality and economy. Generally cement and coarse aggregates is factory made products and their quality and standards can be easily controlled and maintained. Water used for mixing of concrete is usually tap water. The fine aggregates or sand used is usually obtained from natural sources specially river beds or river banks. Now-a-days due to constant sand mining the natural sand is depleting at an alarming rate. Sand dragging from river beds has led to several environmental issues. Due to various environmental issues Government has banned the dragging of sand from rivers. This has led to a scarcity and significant increase in the cost of natural sand. There is an urgent need to find an alternative to river sand. The only long term replacement for sand is manufactured sand. Glass is used in many forms in day-to-day life. It has limited life span and after use it is either stock piled or sent to landfills. Since glass is non-biodegradable, landfills do not provide an environment friendly solution. Hence, there is strong need to utilize waste glasses. Many efforts have been made to use waste glass in concrete industry as a replacement of coarse aggregate, fine aggregate and cement. Concrete is a construction material composed of cement, aggregates ( fine and coarse aggregates) water and admixtures, Today many researches are going into the use of Portland cement replacements, using many waste materials like pulverized fly ash, ground granulated blast furnace slag (GGBS) etc. Like ways a waste glass powder (GLP) is also used as a binder with partial replacement of cement which take some part of reaction at the time of hydration, also acts as a filler material. In this study, waste glass powders have been used as a partial replacements to the concrete ingredient i.e. cement and the mechanical properties like compressive strength and split tensile strength are measured. For checking strength effect of replacement of cement by glass powder, the cement is replaced at 5\%, 10\%, 15\%, $20 \%$ and $25 \%$. Generally cement and coarse aggregates is factory made products and their quality and standards can be easily controlled and maintained, water usually is a tap water. Fine aggregates are usually natural sand. Now days due to constant sand mining the natural sand is depleting at an alarming rate. Due to various environmental issues government has banned the dragging of sand and has led to scarcity and cost effective. The only long term replacement for sand is manufacture sand. It is found that up to $15 \%$ addition of GLP gives higher strength. And also GLP size less than 90 micron is very effective in enhancement of strength.
\end{abstract}

Keywords: Cement, Waste glass powder, M-sand, Natural Sand.

\section{INTRODUCTION}

Natural resources are of two types- the renewable and the non-renewable. Renewable resources which can be recycled again and again which are utilized for our benefits. But nonrenewable resources are those, which once removed and utilized are lost forever. The major problem facing by mankind today is about the utilization of natural resources in order to meet the human needs and maintain the economic growth without exhausting the resources and endangering the environmental integral on which life economic prosperity and our security depend. The worldwide utilization of regular sand is high because of the broad utilization of cement. Specifically, the interest for regular sand is high in creating nations inferable from quick infrastructural development, buildings and different structures since cement assumes the critical part and a substantial quantum of its being used. The primary driver of substitution and less utilization of common sand is because of the non-renewable nature of characteristics sand the relating expanding interest of development industry. In this manner searching for a substitution to stream sand has turn into a need and major issue. The least expensive and simplest distinct option for normal sand is assembling sand by pulverizing rocks/stones in coveted size and grade by suitable strategy. Sand delivered by such means is known as produced/crusher/simulated sand.

Like PFA and GGBS, a glass powder (GLP) is additionally utilized as a cover with halfway substitution of bond which takes some piece of response at the season of hydration; likewise it go about as a filler material. Today numerous explores are continuous into the utilization of Portland concrete substitutions, utilizing numerous waste materials and mechanical by items, for instance, pummeled fly cinder (PFA) and ground granulated impact heater slag (GGBS). The term glass contains a few substance mixtures including parallel antacid silicate glass, boro-silicate glass, and ternary pop lime silicate glass: fractional supplanting of bond with 
processed waste glass advantages the microstructure and solidness of cementitious materials. A denser (not so much permeable) but rather more homogenous structure is created when processed waste glass is utilized as halfway trade for bond, which advantages the imperviousness to dampness retention and accordingly the long haul strength of cementitious materials.

Fractional supplanting of bond with processed waste glass likewise advantages the soundness of cementitious materials when possibly pernicious responses between concrete hydrates and the responsive aggregates is a worry.

Broad studies were attempted to take care of issues, for example, the salt silica response (ASR), major natural, vitality, and expense funds can be acknowledged by fractional supplanting of concrete with processed blended shading waste glass. Supplanting concrete by pozzolanic material like waste glass powder in cement, not just expands the quality furthermore presents economy additionally upgrades the toughness. Assembling procedures, administrations commercial enterprises and civil strong squanders are the wellsprings of creation of various waste materials. Issues related with transfer of the produced squanders have colossally expanded with the expanding mindfulness about the earth. Strong waste administration is one of the major natural issues confronting by the world today. Waste usage has turn into one of the best alluring distinct options for transfer as a result of the shortage of space for area filling and because of its constantly expanding expense. Subsequently, because of utilization of such waste items in cement makes it efficient, as well as aides in diminishing transfer issues. Reuse of cumbersome squanders is viewed as the best ecological option for taking care of the issue of transfer in today's cutting edge life.

\section{MATERIALS}

A gigantic measure of cement is devoured by the development business. It has supplanted old development materials, for example, block and stone brick work, because of its capacity to get cast in any structure and shape. The quality and solidness of solid can be changed by rolling out fitting improvements in its fixings like cementitious materials, total and water furthermore by including some uncommon fixings. Henceforth concrete is exceptionally appropriate for an extensive variety of utilizations. Yet, cement has a few lacks, for example, low elasticity, low post breaking limit, brittleness and low malleability, constrained weariness life, not fit for obliging huge disfigurements, low effect quality.

\subsection{Cement}

Cement is a binding material in concrete with adhesive and strong properties and it is to an extraordinary degree fine grounded material. 53 grade ordinary Portland cement is utilized in the present examination.

\subsection{Waste Glass Powder}

Waste glasses are accumulated from exchange region territory and granulated it to powder or into cementitious frame as to procure certain degree of concrete substitution. After that, glass powder was procured by squashing waste glass pieces in a cone crusher factory. The 90 micron passing parts were used for the experimentations as shown in FIG 1. Chemical composition of glass powder is demonstrated in Table $\mathbf{1}$ and oxide substance of waste glass powder is indicated in Table 2 . It has been developed that extension of finely grained glass to Portland concrete cement revives the coupling strategy amid preinduction time of hydration (2-4 min) yet blocks it in the midst of inciting period. Notwithstanding, this does not impact the mechanical strength of the concrete examples after first day of solidifying. The quality of tests with glass is higher as stood out from the control tests, because, as communicated earlier, glass included substances change cement stone structure. The execution of solid containing glass powder as incomplete substitution of Portland cement was halfway supplanted with $0-25 \%$ glass powder. Specific gravity property of waste glass powder is basic in the concrete outline.

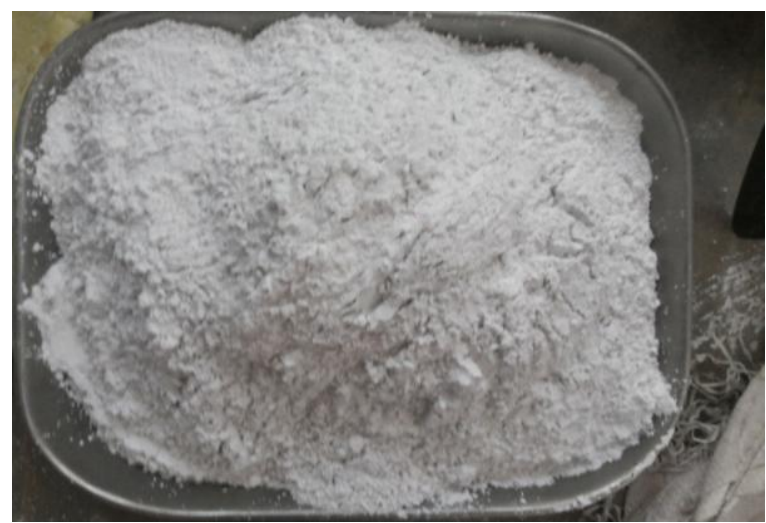

Fig-1: fine grounded waste glass powder of 900 micron sieve size

Table 1 Chemical Composition of Waste Glass Powder

\begin{tabular}{|l|l|}
\hline COMPOSITION & $\begin{array}{l}\text { GLASS } \\
\text { POWDER }\end{array}$ \\
\hline $\mathrm{SiO}_{2}$ & 72.42 \\
\hline $\mathrm{Al}_{2} \mathrm{O}_{3}$ & 0.44 \\
\hline $\mathrm{TiO}_{2}$ & 0.035 \\
\hline $\mathrm{Cr}_{2} \mathrm{O}_{3}$ & 0.002 \\
\hline $\mathrm{Fe}_{2} \mathrm{O}_{3}$ & 0.07 \\
\hline $\mathrm{CaO}$ & 11.50 \\
\hline $\mathrm{MgO}$ & 0.32 \\
\hline $\mathrm{Na}_{2} \mathrm{O}$ & 13.64 \\
\hline $\mathrm{K}_{2} \mathrm{O}$ & 0.35 \\
\hline $\mathrm{SO}_{3}$ & 0.21 \\
\hline
\end{tabular}

Table 2 Oxide Content of Glass Powder

\begin{tabular}{|l|l|}
\hline Oxide & Content (\%) \\
\hline $\mathrm{SiO}_{2}$ & 72 \\
\hline $\mathrm{Na}_{2} \mathrm{O}$ & 14 \\
\hline $\mathrm{CaO}$ & 9 \\
\hline
\end{tabular}




\begin{tabular}{|l|l|}
\hline $\mathrm{Al}_{2} \mathrm{O}_{3}$ & 2 \\
\hline $\mathrm{MgO}$ & 2.2 \\
\hline $\mathrm{K}_{2} \mathrm{O}$ & 0.5 \\
\hline $\mathrm{Fe}_{2} \mathrm{O}_{3}$ & 0.2 \\
\hline $\mathrm{Cr}, \mathrm{S}, \mathrm{Co}$ & 0.1 \\
\hline
\end{tabular}

\subsection{Coarse Aggregates}

Aggregates are one of the imperative constituents of concrete and they constitute about 75 to $80 \%$ of total volume of concrete. They help in decrease of shrinkage and influence economy as it were. Following are some of properties of aggregates, which the impact concrete. Coarse aggregate is the most grounded and scarcest penetrable part of concrete. It is all around that pounded stone aggregate lead to higher qualities than adjusted ones. In the present examination, provincially accessible smashed rock of size 20 and $1.5 \mathrm{~mm}$ in the degree of $67 \%$ and $33 \%$ exclusively by volume were used.

\subsection{Fine Aggregate (Natural Sand)}

By regional standards accessible stream sand has been utilized as fine aggregate as a part of the present investigation. Sand was tried for their physical attributes as indicated in Table 4.5 which were directed in laboratory.

\subsection{Fine Aggregate (M-Sand)}

M-sand available from a local quarry was selected in this investigation and the following results for laboratory tests were obtained as mentioned in Table 4.7. The M-sand used for preparation of concrete moulds falls in zone II as per IS 383-1970.

\subsection{Water}

Water is an crucial component of concrete as it is viably included in chemical responses with cement, particularly hydration. In the present examination consumable water is used according to IS 456: 2000 was used for preparation of cement, the water concrete proportion chooses the quality of cement. It is an adequately taking an interest constituent material in the synthetic response with bond. The workability of the concrete is controlled by various components, for instance, the beginning measure of water, the reactivity of cement, the measure of superplasticizer and its level of comparability with the particular concrete.

\subsection{Superplasticizer}

Master Rheobulid 1125 is utilized which is made out of engineered polymers that is basically intended impressive diminishment in blending of water while keeping up control on reach out of hindrance. It serves to accomplish elite cement with longer workability maintenance.

\section{EXPERIMENTAL PROGRAMME}

In this experimental investigation an attempt has been made to find out the strength of concrete produced by replacing the cement with waste glass powder in various percentages ranging from $5 \%$ to $25 \%$ in increments of $5 \%[0 \%, 5 \%$, $10 \%, 15 \%, 20 \%$, and 25\%]. Ordinary Portland cement (OPC) 53 grade, locally available M-sand and coarse aggregates were used in this experiments. The sand used was a Zone II had the specific gravity 2.6. the specific gravity of the coarse aggregate was 2.59. the coarse aggregate used were of $12 \mathrm{~mm}$ and down size. To impart workability to the mix, a superplasiticizer (rheobuild 1125) from a reputed company was used with the dosage of $0.8 \%$ by weight of cement. The glass powder was obtained by crushing waste glass pieces in a cone crusher mill. The 900 micron passing fraction was used for the experimentation. Mix design carried out for M30 as per IS 10262:2009 yielded a mix proportion of 1: 1.7: 2.7 with water cement ratio of 0.45 . Specimens were prepared according to the mix proportion and by replacing cement with glass powder in different proportion and use of M-sand. An increasing trend in compressive strength and flexural strength was observed with increasing replacement of cement. To find out compressive strength, split tensile strength and flexural

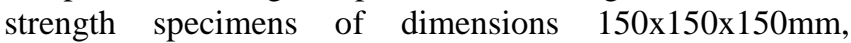
$150 \times 300 \mathrm{~mm}$ and $150 \times 150 \times 700 \mathrm{~mm}$ were cast and tested as per IS 516:1959. Details of mix content with constant coarse aggregate, superplasticizer and w/c ratio I s shown in Table 3.

Table 3 Mix content with constant CA, Superplasticizer and $\mathrm{w} / \mathrm{c}$ ratio

\begin{tabular}{|c|c|c|c|c|c|c|}
\hline \multirow{2}{*}{$\begin{array}{l}\text { WGP and } \\
\text { M-sand } \\
\text { replaceme } \\
\text { nt }\end{array}$} & \multicolumn{4}{|c|}{ Mix Proportion $\left(\mathrm{kg} / \mathrm{m}^{3}\right)$} & \multirow[b]{2}{*}{ W/C } & \multirow[b]{2}{*}{$\begin{array}{l}\text { SP } \\
(\%)\end{array}$} \\
\hline & $\mathbf{C}$ & $\begin{array}{l}\text { WG } \\
\text { P }\end{array}$ & $\begin{array}{l}\text { M- } \\
\text { sand }\end{array}$ & $\mathbf{C A}$ & & \\
\hline $0 \%$ & $\begin{array}{l}40 \\
0 \\
\end{array}$ & 0 & $\begin{array}{l}683 . \\
69\end{array}$ & $\begin{array}{l}1111 . \\
22\end{array}$ & 0.45 & 0.8 \\
\hline $5 \%$ & $\begin{array}{l}38 \\
0\end{array}$ & 20 & $\begin{array}{l}683 . \\
69\end{array}$ & $\begin{array}{l}1111 . \\
22\end{array}$ & 0.45 & 0.8 \\
\hline $10 \%$ & $\begin{array}{l}36 \\
0\end{array}$ & 40 & $\begin{array}{l}683 . \\
69\end{array}$ & $\begin{array}{l}1111 . \\
22\end{array}$ & 0.45 & 0.8 \\
\hline $15 \%$ & $\begin{array}{l}34 \\
0 \\
\end{array}$ & 60 & $\begin{array}{l}683 . \\
69\end{array}$ & $\begin{array}{l}1111 . \\
22\end{array}$ & 0.45 & 0.8 \\
\hline $20 \%$ & $\begin{array}{l}32 \\
0 \\
\end{array}$ & 80 & $\begin{array}{l}683 . \\
69\end{array}$ & $\begin{array}{l}1111 . \\
22\end{array}$ & 0.45 & 0.8 \\
\hline $25 \%$ & $\begin{array}{l}30 \\
0\end{array}$ & 100 & $\begin{array}{l}683 \\
69\end{array}$ & $\begin{array}{l}1111 . \\
22\end{array}$ & 0.45 & 0.8 \\
\hline
\end{tabular}

\section{TEST RESULTS}

Table 4 Slump Test results

\begin{tabular}{|l|l|}
\hline \% replacement of WGP & Slump value \\
\hline Conventional concrete & 75 \\
\hline $5 \%$ & 74 \\
\hline $10 \%$ & 72 \\
\hline $15 \%$ & 69 \\
\hline $20 \%$ & 67 \\
\hline $25 \%$ & 64 \\
\hline
\end{tabular}


Table 5 Compressive Strength results

\begin{tabular}{|c|c|c|c|c|}
\hline \multirow[t]{2}{*}{ SL.NO } & \multirow{2}{*}{$\begin{array}{l}\text { \% } \\
\text { VARIATION } \\
\text { OF WGP }\end{array}$} & \multicolumn{3}{|c|}{$\begin{array}{l}\text { COMPRESSIVE } \\
\text { STRENGTH(N/mm²) }\end{array}$} \\
\hline & & 7 days & 14 days & 28 days \\
\hline 1. & $0 \%$ & 18.23 & 22.45 & 33.34 \\
\hline 2. & $5 \%$ & 25.62 & 36.47 & 40.67 \\
\hline 3. & $10 \%$ & 37.18 & 39.38 & 44.47 \\
\hline 4. & $15 \%$ & 40.29 & 42.23 & 44.59 \\
\hline 5. & $20 \%$ & 36.47 & 39.11 & 40.59 \\
\hline 6. & $25 \%$ & 26.88 & 31.24 & 35.43 \\
\hline
\end{tabular}

Table 6 Split Tensile Strength results

\begin{tabular}{|l|l|l|l|l|}
\hline \multirow{2}{*}{ SL.NO } & \multirow{2}{*}{$\begin{array}{l}\text { \% } \\
\text { VARIATION }\end{array}$} & \multicolumn{3}{l|}{$\begin{array}{l}\text { TENSILE } \\
\text { STRENGTH(N/mm }\end{array}$} \\
\cline { 3 - 5 } & OF WGP & 7 days & $\mathbf{1 4}$ days & $\mathbf{2 8}$ days \\
\hline 1. & $0 \%$ & 1.72 & 1.98 & 2.26 \\
\hline 2. & $5 \%$ & 2.04 & 2.31 & 2.73 \\
\hline 3. & $10 \%$ & 2.41 & 2.54 & 2.96 \\
\hline 4. & $15 \%$ & 2.61 & 2.78 & 3.15 \\
\hline 5. & $20 \%$ & 2.26 & 2.41 & 2.54 \\
\hline 6. & $25 \%$ & 1.98 & 2.13 & 2.31 \\
\hline
\end{tabular}

Table 7 Flexural Strength results

\begin{tabular}{|l|l|l|l|}
\hline SL.NO & \multirow{2}{*}{$\begin{array}{l}\text { VARIATION } \\
\text { OF WGP }\end{array}$} & $\begin{array}{l}\text { FLEXURAL } \\
\text { STRENGTH }\left(\mathbf{N} / \mathbf{m m}^{\mathbf{2}}\right)\end{array}$ \\
\cline { 3 - 4 } & & 28 days & $\mathbf{5 6}$ days \\
\hline 1. & $0 \%$ & 2.92 & 4.34 \\
\hline 2. & $5 \%$ & 3.39 & 5.56 \\
\hline 3. & $10 \%$ & 4.61 & 6.37 \\
\hline 4. & $15 \%$ & 5.63 & 7.59 \\
\hline 5. & $20 \%$ & 4.14 & 5.68 \\
\hline 6. & $25 \%$ & 3.79 & 4.01 \\
\hline
\end{tabular}

\section{DISCUSSION ON TEST RESULTS}

Thus, there is improvement in compressive strength because of continuous increase of waste glass powder. The strength increases with addition of waste glass powder at 5\%, $10 \%$ $15 \%$ and after that declines at $20 \%$ and $25 \%$ gradually because of more alkali silica reaction freed during hydration of cement.

The aftereffects of split tensile strength of concrete mixes by partial substitution of cement by waste glass powder and utilizing of M-sand as fine aggregate was tested at 7, 14 and 28 days. Thus result tensile of concrete increases with expansion in rate of waste glass powder which can be supplanted up to $20 \%$ as indicated in graphical representation.

The consequences of flexural strength of concrete mix M30 by fractional supplanting of cement with waste glass powder were tested at 28 and 56 days, the concrete with addition of $5 \%, 10 \%$ and $15 \%$ of waste glass powder demonstrated most extreme strength when contrasted to conventional concrete.
The increase in strength up to $15 \%$ replacement of cement by waste glass powder may be due to pozzolanic reaction of glass powder and it may be due to the glass powder effectively filling the voids and giving rise to dense concrete microstructure. However, beyond $20 \%$ the dilution effect takes over and the strength starts to drop. Thus it concludes that $20 \%$ was the optimum level for replacement of cement with glass powder. The following figures represents graphical comparison of strength obtained by the experimentation.

\section{slump vaue}

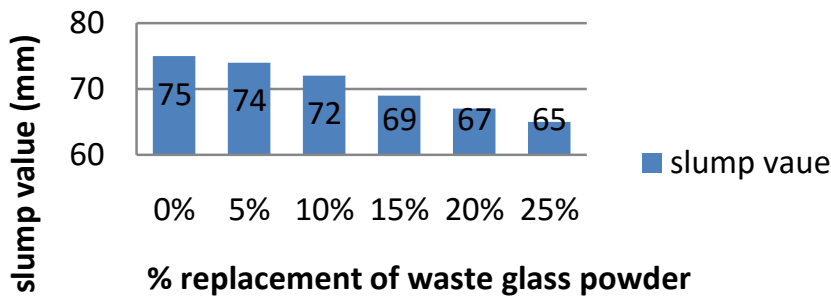

Fig- 2: Slump value of M30 grade concrete

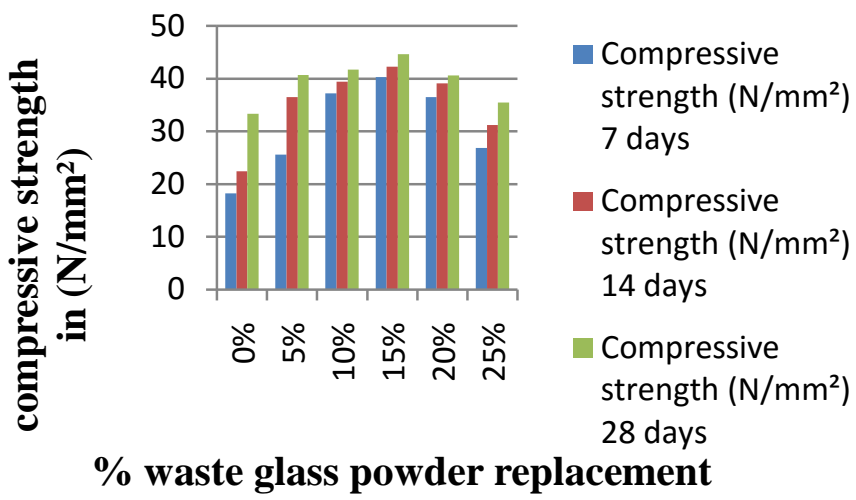

Fig-3: Comparison of compressive strength for 7, 14, and 28 days

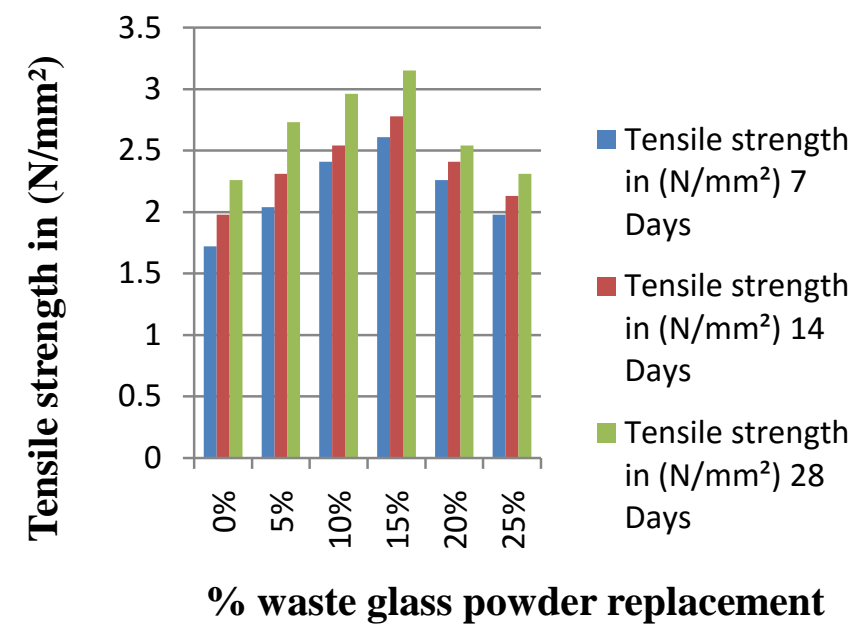

Fig-4: comparison of tensile strength of concrete 


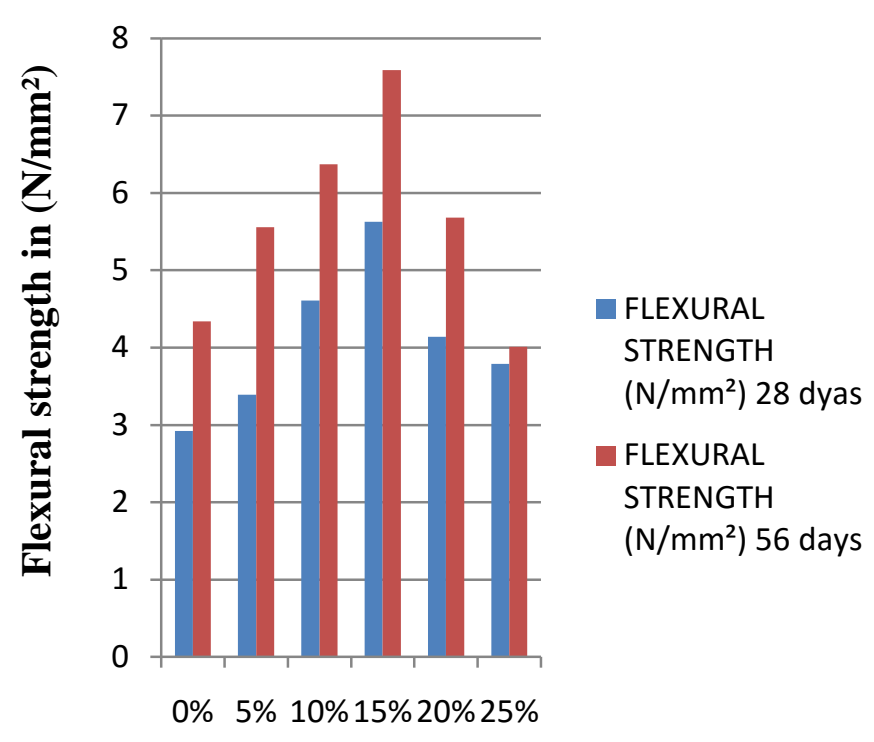

$\%$ waste glass powder replacement

Fig-5: comparison of flexural strength of concrete

\section{CONCLUSION}

1. Utilizing waste glass powder it is conceivable to diminish the utilization of concrete and the related vitality interest effect on air contamination and $\mathrm{Co}_{2}$ emanation. The slump of concrete appears to increment in glass powder in the concrete mix. At $10 \%$ glass powder content, the compressive strength of concrete is higher than that of the control. Over $20 \%$ glass powder the quality significantly decreases.

2. As a conclusion, all the destinations of this study are accomplished; concrete with utilizing waste glass powder has a high workability from control test. The outcome accomplished from the slump test clarifies that by utilizing waste glass powder will expand the workability of concrete. In term strength, concrete with using waste glass powder averagely have higher strength at 14 days yet once the concrete reached at 28 days the control mix give more higher worth contrast with mix that contained waste glass powder yet at the same time give high value for M30.

3. From this study, it can be concluded that utilizing waste glass powder is giving positive esteem notwithstanding when worth is contrasted with standard mix it only less about $1 \mathrm{~N} / \mathrm{mm}^{2}$.

\section{FUTURE RECOMMENDATION}

1. Strength can be analyzed by partially supplanting cement and fine aggregate by waste glass powder and M-sand.

2. Utilization of waste glass powder finer than 75 micron as fractional substitution with cement and analyzing strength. 3. Strength can be dissected by partially supplanting cement and fine aggregate by waste glass powder finer than 90 micron and holding on 150 micron separately.

\section{ACKNOWLEDGEMENTS}

My humble and heartfelt thanks to my guide Chandrakala $S$, Assistant professor Department of civil engineering, S J C Institute of Technology. Chickaballapur. Thanks to my dear friends who have supported me to complete this work.

\section{REFRENCES}

[1]. Shanmugapriya T and Uma R N (2012, "Optimization of Partial Replacement of M-sand by Natural sand in High Performance concrete with silica fume", International Journal of Engnieering Sciences and Emerging Technologies, Vol-2, pp-73-80.

[2]. Shyam Prakash (2013), "Mechanical properties of Msand depend on raw material", International Journal of Structural and Civil Engnieering Research, ISSN 23196009, November Vol-2, N0-4.

[3]. Nimitha Vijayaraghavan (2013), "Environmental issues on use of natural sand and cost", International Journal of Structural and Civil Engnieering Research, Vol-2, N0-4.

[4]. Mhendra R Chitlange and Prakash S Pajgade (2010), "Strength Appraisal of Artificial Sand as Fine Aggregate", In SFRC Asian Research Publishing Network, Journal of Engnieering and Applied Sciences, Vol-5, pp-34-38.

[5]. Gunalaan, Vasudevan (2013), "using waste glass powder in concrete mix", American Journal of Engnieering Research, ISSN: 2320-0936, Vol-2, Issue-12, pp-175-181.

[6]. C.D Arun Kumar \& K.Sakthimurugan (2013) "Study of waste glass powder as pozzolanic material in concrete", Journal Built Expressions, Vol-2, Issue-5.

[7]. Dr. Professor Narayan (2013), "Investigation of the potential of using waste glass generated", American Journal of Engnieering Research, Vol-2, PP-175-181.

[8]. Chief Scientist Ahmed Shayan (2013), "Value added by the utilization of Waste glass in concrete", American Journal of Engnieering Research, Vol-2, Pp-175-181.

[9]. Dr. Vanitha Agarwal (2014), "Effect of Using Glass Powder in concrete", International journal of Innovative Research in Science, Engnieering and Technology, Vol-3, Issue-7.

[10]. R.Vanghiyan (2013), "Workability by replacement of cement with waste glass", International Journal of Innovative Research in Science, Engnieering and Technology, Vol-3, Issue-7.

[11]. Vasudevan Gunalaan and Kanapathy Pillay Seri Ganis (2013), "Improvement in compressive strength of Concrete mix by use of waste glass powder".

[12]. Kumarappan N (2013), "compressive strength of glass powder concrete", International Journal of Engnieering Research and Technology ISSN: 2278-0181 Vol-2, Issue10.

[13]. Dr.Keshav K.Sangle (2013), "Effect of mechanical strength of replacement of cement of glass powder", International Journal of Advanced Technology in Civil Engnieering, ISSN: 2231-5721, Vol-2, Issue-1.

[14]. M.N.Bajad (2010), "Development of Concrete containing waste glass as pozzolana", Journal of Information, Knowledge and Research in Civil Engnieering, ISSN: 0975-6744, Vol-1, Issue-1. 
[15]. M.S Shetty. (2002), “Concrete Technology: Theory and Practice", S.Chand and company ltd. New Delhi, India, $5^{\text {th }}$ Edition.

\section{BIOGRAPHIES}

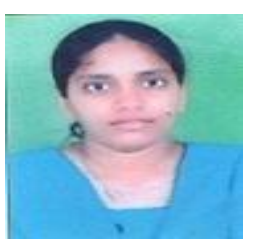

Ms Shruthi S, Pursuing Final year

M.Tech in SJC Institute of Technology Chickaballapu. Completed my Under Graduation in Government Engineering College, Kushalnagar under VTU.

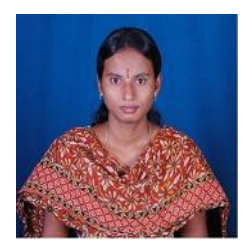

Mrs. Chandrakala S, Asst Prof, SJC Institute of Technology Chickaballapur. Under Graduation under VTU. Post graduation(Structural Engineering) at SJCIT Chickaballapur. She had very wide Experience over 6 years in Technology.

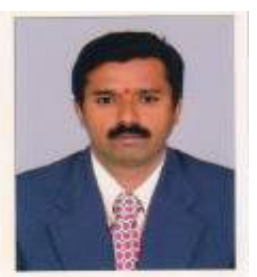

Dr. G Narayana, Professor and Head of Department, Department of Civil Engineering SJC Institute of Technology-Chickaballapur. He had very wide experience of Teaching and Research in the Field of Structural Engineering, also a structure designed consultant for many projects. 